\title{
Does Foreign Direct Investment (FDI) Really Matter in Developing Countries? The Case of Egypt
}

\author{
Mohamed Masry ${ }^{1}$ \\ 1 Accounting and Finance Department, Faculty of Business Administration, Arab Academy for Science and \\ Technology (AAST), Miami, Alexandria, Egypt
}

Correspondence: Mohamed Abdel Fattah Masry, PhD, MA, MBA, BA in finance: Accounting and Finance Department, Faculty of Business Administration, Arab Academy for Science and Technology (AAST), Miami, Alexandria, Egypt. Tel: 20-3-556-5429/548-1163.

Received: November 20, 2015

doi:10.5430/rwe.v6n4p64
Accepted: December 6, $2015 \quad$ Online Published: December 13, 2015

URL: http://dx.doi.org/10.5430/rwe.v6n4p64

\begin{abstract}
The main purpose of this paper is to examine the various factors that attract Foreign Direct Investment (FDI) in developing countries, in order to find answers to the following question: Does foreign direct Investment really matters in developing countries? The study investigates the relationship between FDI and the economic growth in Egypt as a good indicator for developing countries, covering the period 1961-2012. Results from the analysis suggest that FDI is explained by some economic determinants but has non- significant effect on GDP growth. The study also investigates FDI Behavior in Egypt and explaining this behavior and the impact of FDI on activating the Egyptian stock exchange between $1996-2012$.
\end{abstract}

Keywords: foreign direct investment, economic growth, determinants of FDI, Egyptian Stock Exchange

\section{Introduction}

In the last decade, and beginning of the 21th century, one of the most infamous features of the new trends to Foreign Direct Investment (FDI) has been the improved contribution of developing economies in the world economy. This comparative importance is not only associated with their position in the world trade, but also, in terms of the flow of new competitive companies operating globally, in different forms; sale subsidiaries, production subsidiaries, with Greenfield FDI and acquiring high competitive firms in developing countries.

On the last two decades, the FDI funds developing countries rose at a higher year average than those from developed countries, and their outward stock extended more than $15 \%$ of the world FDI outward stock, compared with a performance of less than $10 \%$ in the 90 s. Numerous studies have expected that this growing performance would continue on the coming years. Successful business model, sizeable assets and cheaper access to capital will lead developing countries to challenge even more developed economies (Santiso, 2007). Latest financial performance boosted the FDI stocks level of developing countries and made them less dependent upon international banking loans to finance their foreign investments projects (UNCTAD, 2013), and the assets and stocks depreciation of firms in developed countries due to the global crisis may have contributed significantly to increase the influence of developing countries in the world FDI market share throughout new acquisitions (ECLAC, 2009).

Although, it is progressing among economists that FDI positively affect economic growth, however they did not identify who benefit more host country or home country? (Lipsey, 2002). As a result an empirical finding was misleading sometimes. Also there is no general consensus among the literature on the determinants of FDI. Through this theoretical controversy there is a main question dominating the FDI literature. Does FDI really matters in developing countries? Security markets is an important sub financial market and it is a long term investment compared to money market as its main function is collecting community's savings and using in purchasing securities, in this markets, savings are converted to capitals and loans to organisations applying various activities in community in conformity with real investment development and in turn, increasing employment and growth in nation economy.

In an attempt to review security market in Egypt to play its development role, Egyptians government followed a program of economic and financial reform aiming at improving environment organising tasks of such exchange and removing restrictions on foreign cash for foreign investors in Egyptian stock exchange, so that this program freed 
entrance and exit of capitals from all restrictions, although there are many different opinions about capital movement freedom, as financial markets globalisation increases in the last two decades, financial freedom accelerated and role of foreign capital transfer aggrandised in the 1990s, as capital financial deals formed about five times commercial exchange and, for developing countries, cash flows accelerated to such countries in many forms including direct investments and others in portfolio.

\subsection{The Research Importance}

As developing countries suffer from lack of low finance sources for supporting their development projects, they looked for alternative foreign sources to advance development levels represented in many forms including foreign loans and investments due to hazards in financing economic development, attentions were paid to using direct foreign investment as an economic growth engine contributing in increasing local economy productivity abilities as foreign investment study is a wide field and depending its important role in the receiving developing economies, identifying role of foreign investment is important in general in accelerating GDP growth, new created securities market and in particular in Egyptian stock exchange.

\subsection{The Research Problem}

Despite following economic and legal policy for increasing flows of indirect foreign investment to developing countries, there are risks and restrictions affecting direct foreign investment and, accordingly, limiting foreign capitals from which such countries profit accordingly, this study deals with role of direct foreign investment in Egyptian stock exchange activation. This study aims at answering does FDI really matters in Egypt, as a developing country, available by direct foreign investment in countries looking for and how far direct foreign investment contributes to GDP growth and in the development of the Egyptian Stock Exchange.

\subsection{The Research Questions}

This study addresses an area that has been so far neglected by the existing literature. It focuses on unresolved issues concerning FDI and its impact on one of the developing countries, more specifically Egypt. In addition, the determinant of FDI, GDP growth, its behaviour, and the influence of FDI on activating Egyptian stock exchange. To help find answers to the issues raised and to structure the study, the following general research question is set and its sub questions highlighted:

General Research Question: Does FDI really matters in Developing countries? Throughout studying the case of Egyptian experiment.

Research Sub questions: the above-stated general research question can be broken down into a more detailed question as follows:

1. What are the most important determinants of FDI in Egypt?

2. What is the impact of FDI on GDP growth in Egypt?

3. What is the FDI behaviour in Egypt between the periods of 1990-2012?

4. What is the impact of FDI on activating Egyptian stock exchange between the periods of 1996-2012?

\section{Theoretical Framework of the Study}

Asa result of the mounting importance of developing countries FDI in the present world economy, their impact in the Literature has grown in importance in the same pace. The theoretical framework of the study can be classified in to three main perspectives. A FDI perspective, which is more focused on signifying empirical and theoretical models to understand the strategies of developing countries and the determinants of the Outward FDI from developing economies. The second perspective is the institutional perspective, which dedicated on how organisations from home and host countries of FDI affect the international expansion of firms. The third perspective is the managerial perspective which is more related to studies that have addressed differences and similarities of the internationalisation processes of Multinational companies companies (MNCs) from countries with different level of development (Developed and developing economies).

First, from the FDI perspective, it is supposed that developing countries share some common characteristics, such as the comparative advantages related to the factor endowment resources in their home countries and the easy access to natural resources (BCG, 2009) and the comparative advantages related to the factor benefaction funds in their home countries, that let them to be globally competitive due to their low prices (Enderwick, 2009; Pangarkar and Lim, 2003). 
Second, from the institutional perspective, the FDI theory has conventionally seen the macroeconomic variables as the country of origin elements responsible for the international performance of MNCs. After some studies exposed the deficient markets operating, the economists' perception of other elements affecting the FDI grew (Amal et al., 2009). The institutions role is related to their ability to develop the markets' structure efficiency by reducing information and transaction costs and also the instability and uncertainty levels (Mudambi and Navarra, 2002). Bevan et al. (2004) understand that both government arrangements and informal institutions should affect corporate approaches. Given the institutions importance on enhancing markets efficiency, Peng et al. (2008) see them as main process in improving the competitiveness of firms in developing countries, as their institutions differ considerably from those from developed economies. The academics define institutions as a structure responsible for managing transactions on politics (such as corruption and transparency), community behavior interaction, social (such as business climate and ethical rules) and law (such as regulatory regime and economic freedom).

While from the third perspective, the managerial perspective, foreign firms face different barriers of entries that exist owing to different levels of psychological, geographic distance, institutional and cultural relationship between the country of origin and host countries of their investments (Nachum, 2003), the barriers are often called "Liability of foreignness (LOF). According to Madhok (2010), LOF arises for some reasons:

- Foreign companies have difficulties related to the low level of knowledge about host markets of their investments;

- Companies need to adapt their ownership advantages to different institutional and cultural environments, which would generate different barriers and costs that national firms do not have; and

- Finally, foreign companies should institute legitimacy and be accepted into the host country.

In conclusion, the Finance theorists have debated and classify the determinants and impacts of FDI. The first group believes in the idea that FDI produces economic benefits to the mother countries more than host countries by using the cheap labour and resources, as well as, enjoying the investment incentives provided by host countries without providing a value added support to the development process or technology transfer. In addition to that, most of developing countries has low savings rate, which results in low rate of investment and hence, low per capita income growth rate.

On the other hand, the other group assumes the idea that FDI yields in economic benefits to the host countries by providing advanced technology, capital, access to foreign markets and competition. Also, FDI can improve innovation and national investment. Therefore, FDI has positive effects on developing countries economy because: FDI delivers capitals needed for developing countries and avoid undesirable effects associated with other forms of capital flows (Masry, 2015c). Moreover, FDI doesn't provide only essential funding to developing countries, but also the most effective management techniques. Moreover, FDI is stable funding methods compared with other funding methods such as stock market investments and hot money transfer.

In short, most of the developing countries are competing with each other to attract reasonable amount of FDI by adopting different attraction policies, such as offering incentives to the foreign investors, and liberalising trade system establishing special economic zones. In addition to the above, the national company motives to access foreign markets can facilitate the success of FDI in developing countries. These motives have some assumptions: first, Companies aim is maximising profits, it means that FDI is a function in return on investment between different countries, which was prevails in the fifties (Hymer, 1976). Second, there is a positive relationship between foreign trade volume and FDI (Chakrabarti, 2003).Third; there is a negative relationship between political risk degree and FDI (Agarwal, 1980). Fourth, there is a positive relation between investment incentives and FDI, small businesses has a positive relation greater than large companies which have better experience in developing countries markets (Aharoni, 1999).Fifth, there is a positive relation between the cost of labour wages and FDI, the study of James (1975) proved that the low cost of labour is the most important determinants attracting FDI to developing countries.

\section{Previous Studies}

There are many studies such as (Dbwona 2001, Asiedu 2002, Akhtar 1993, Collier and Pattillo, 2000) has been identify the most important determinants for attracting FDI in, for instance, human capital, infrastructure, market size, exchange rate, proximity to major markets, the degree of openness to the outside world, tax incentives, monetary policy, political stability, investment environment, judicial transparency, regulatory framework, red tape and bureaucratic hurdles, and the extent of corruption in the host country). Wheeler and Mody, (1992) found that administrative efficiency and political risk are insignificant in determining FDI. While Root and Ahmed (1979) found that riots, political strikes, and regular constitutional changes in government significantly determine FDI inflow. The mixed result might stems from the problems of getting consistent alternatives for the qualitative 
phenomena, such as international business cycle movement and political instability. Badr and osama (2015) investigates the relationship between FDI and the economic growth in the North African countries, covering the period 1961-2012. Outcomes of the analysis recommend that FDI is clarified by some economic factors but has nonsignificant effect on GDP growth. Other study by Bhattacharya, Montiel, Sharma (1996), has proven that the rate of market growth indicated by the growth rate of GDP is the greatest significant factors causes in attracting FDI in sub-Saharan Africa. While Banga (2009) Support standpoint that the market size presented by the Growth Domestic Product-itself-is the most influential factor. Another study by Bende-Nabende(2003) divide the determinants into four types: The first is linked to improvement of the investment and business environment, The second is linked to cost side, The third is linked to development strategy pursued by, The fourth is linked to governments the level of macroeconomic variables.

On the other side, there are several studies addressed the impact of FDI on the economic growth.

First, studies those find a positive significant effect for FDI on growth. Such as, Bashir (1999) test the degree of association between economic growth and FDI, employing a sample of Middle East and North Africa (MENA) region. Explain that economic growth has a positive relation with FDI, where FDI leads to economic growth. Gao (2004) assess the impact of FDI on income growth, the study discovers that in all cases, FDI has a positive statistically significant coefficient. Obwana (1996) investigates that FDI had a positive impact on Uganda's growth, although the FDI coefficient was insignificant. Lensink and Morrissey (2001), contribute to the literature on economic growth and FDI by presenting measures of the volatility of FDI inflows. They discover that although FDI has a positive effect on growth, the volatility of FDI has a negative impact. Another important finding of the study is that the evidence on the positive effect of FDI on output growth in the recipient country is not conditional on any other explanatory variable.

Second, studies that find an indefinite role for FDI only on economic growth, but find that FDI when combined with other conditions like financial market development, human development, contributes positively to growth. Such as Carkovic and Levine (2002), inspect the relationship between growth and FDI based on IMF and World Bank datasets; they find that FDI inflows do not exert an independent robust positive influence on economic growth. They show that while sound economic policies may encourage output growth and FDI, FDI does not have a significant effect on output growth that is autonomous of additional growth factors.

In conclusion, the studies on the effects of FDI inflows on national economic growth are inconclusive. Almost all studies find positive effects in some periods or among some groups of countries, in some specifications, with some controlling variables, but these effects cannot be universal as there are circumstances, periods and countries where FDI has insignificant relation with output growth.

\section{Methodology}

This aim of this study is to assess the impact of FDI on one of the developing countries, more specifically Egypt. In addition, the determinant of FDI, GDP growth, its behaviour, and the influence of FDI on activating Egyptian stock exchange. A mixed methods strategy is engaged, using different but complementary data. In this study, some financial indicators for inspecting determinants of FDI in Egypt and the impact of FDI on GDP growth in Egypt are quantitatively analysed. Concurrent with this, qualitative content analysis is used for analysing FDI behaviour in Egypt between the periods of 1990-2012, as well as, the impact of FDI on activating Egyptian stock exchange between the periods of 1996-2012.

The welfares of both methodologies were considered, and the researcher considered that merging features of both qualitative as well as quantitative data was more beneficial, thus making triangulation possible(Masry,2015f). In short, through integrating both approaches together one is able to determine how FDI affected GDP growth in Egypt, the determinant of FDI, its behaviour, and the influence of FDI on activating Egyptian stock exchange and it is possible to gather the requisite data to ensure that the questions of the study are successfully answered.

For answering the first research sub-questions, the study assumed that a country with business friendly environment and large size of GDP with are more likely to be successful in attracting FDI compared to other countries. The variables which represent business friendly environment was High Industry value added, large size of trade, high national reserves, more International relations openness, large Government Expenditure, low Inflation rate, Labor force. The following equation will be estimated:

$\ln (\mathrm{FDI})=\beta 0+\beta 1 \ln (\mathrm{GDP})+\beta 2 \mathrm{INV}+\beta 3 \mathrm{Tr}+\beta 4 \ln ($ Opene $)+\beta 5 \operatorname{Inf}+\beta 6 \ln ($ Reserve $)+\beta 7 \ln (\mathrm{GE})+\beta 8$ Empit $+\varepsilon$ (1)

To examine the second research sub questions, the study assumed that country with large volume if FDI will have positive affects the GDP growth rate. The following equation will be estimated: 


$$
\mathrm{GDPg}=\mathrm{b} 0+\mathrm{b} 1 \ln (\mathrm{FDI})+\varepsilon
$$

With this model a data base was prepared and spreads over 50 years (from 1961 to 2012). This data base was collected from UNCTAD FDI Inflows data base and World Bank Data (WDI) concerns Egypt. The study used multiple linear regressions to test the relationship with a statistic confidence level of up to $10 \%$.

While for the third and the fourth research sub-questions, the study used the qualitative content analysis. The analysis processes involve three main phases: organisation, preparation, and reporting of results. The preparation stage involves collecting suitable data for content analysis, making sense of the data, and selecting the unit of analysis. The organisation phase involves categorisation matrix development, whereby all the data are reviewed for content and coded for correspondence to or exemplification of the identified categories (Polit and Beck, 2012). The categorisation matrix can be regarded as valid if the categories adequately represent the concepts, and from the viewpoint of validity, the categorisation matrix accurately captures what was intended (Schreier, 2012). In the reporting phase, results are described by the content of the categories describing the FDI behaviour in Egypt between the periods of 1990-2012 and the impact of FDI on activating Egyptian stock exchange between the periods of 1996-2012.

\section{The Analysis}

This section includes four main sub-sections organised based on the four research sub questions, the most important determinants of FDI in Egypt, the impact of FDI on GDP growth in Egypt, FDI behaviour in Egypt, and the impact of FDI on activating Egyptian stock exchange

\subsection{Determinants of FDI in Egypt}

As a first part of the research analysis, the study displays the main aspects that attract FDI in Egypt by using multiple regressions which test the effects of a multiple independent variables on one dependent variable. The following table shows the outputs the country with its beta (weight effect) and the statistical significances. In Table 1, it presents the estimated regression models explaining the determinants of FDI. Random effect estimation process has applied for the estimation purpose. To identify the determinants of FDI for Egypt, variables are included in a multiple regression model.

Table 1. Determinants of FDI in Egypt

\begin{tabular}{cc}
\hline Independent variables & FDI in Egypt \\
\hline Ln GDP & $1.713 * *$ \\
Industry, value added (\% of GDP) & 0.344 \\
Trade (\% of GDP) & 0.146 \\
Ln Open & $1.452 * *$ \\
Ln Reserve & $-\mathbf{0 . 0 7 4}$ \\
Ln GE & 0.402 \\
Inflation, consumer prices (annual \%) & $0.641 *$ \\
Employment to population ratio, total (\%) & $0.231 * * *$ \\
The R square test & 0.658 \\
\hline
\end{tabular}

*Significant at $0.01 * *$ significant at $0.05 * * *$ significant at 0.10

Table 2. FDI and GDP growth

\begin{tabular}{cc}
\hline Dependent variable & Egypt \\
\hline GDP g & -0.36 \\
The R square & 0.005 \\
\hline
\end{tabular}

*Significant at $0.01 * *$ significant at $0.05 * * *$ significant at 0.10 
The model consists of the following variables: natural log of GDP, Industry value added, Trade, natural $\log$ of openness, natural log of reserves, and natural $\log$ of General government expenditure, Employment to population ratio, and Inflation. As shown in table1, the main variables those attract more the FDI are, with an order of importance, GDP, economic openness, General Government expenditure and Employment with $\mathrm{R}^{2}$ of $66 \%$.

\subsection{The Impact of FDI on GDP Growth in Egypt}

As a second research sub-question of the study analysis, the result of the effect of the FDI on the growth of the GDP is presented in (Table 2). Thus, the outputs confirmed that the FDI has very weak and non-significant effect on GDP growth in Egypt. This means that the FDI doesn't contribute to the economy growth for Egypt.

\subsection{FDI Behaviour in Egypt between the Periods of 1990-2012}

Egypt was chosen as a case study because it has a significant increase in FDI Inflow during the past period, followed by a significant deterioration. According to UNCTAD reports, FDI inflows to Egypt economy fluctuated between some hundreds of US\$ millions and one thousands of US\$ millions till 2003 it start to increase to reach 12 US\$ billion in 2007 then FDI inflows declaim to be negative in 2011 as shown in Figure 1.

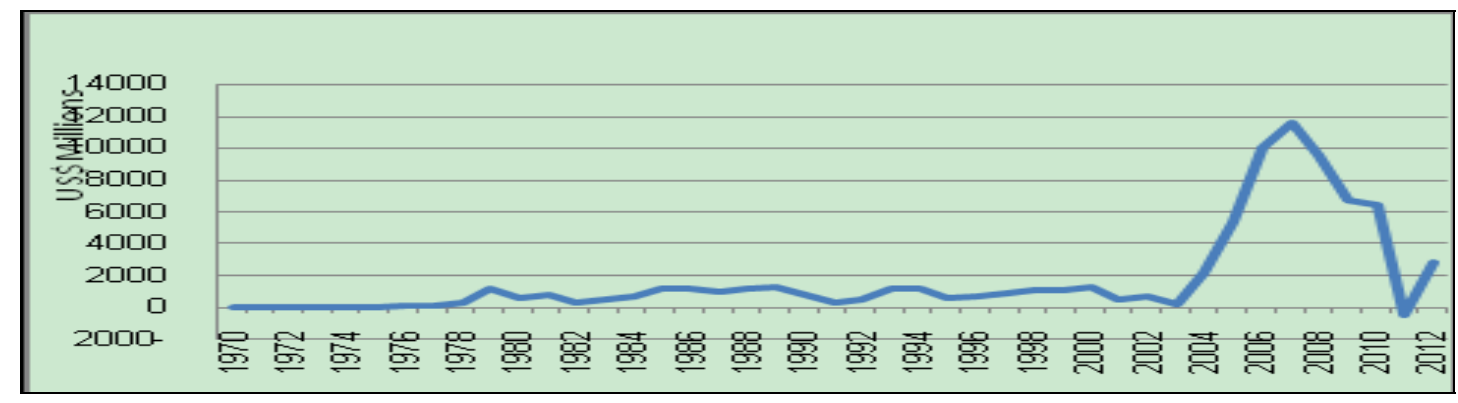

Figure 1. Egypt FDI inflow

In this sub-section, the focus of the analysis is on the Egyptian FDI between 1990 and 2012 with special consideration on last five years (Figure 2 and Figure 3). Although Egypt has made several efforts to attract FDI to Egypt since the mid-nineties, the low flows of FDI in the 90s were mainly owing to two reasons (as shown in Figure 2): First, the lack of professionalism promotion of FDI in Egypt as a result of the absence of economic and political vision which cause lack of a safe environment to FDI which led to decrease the flow of FDI to Egypt, particularly with global competition to attract FDI. Second, decrease the government spending due to Economic Reform and Structural Adjustment Program (ERSAP) launched in 1991.In addition to, adverse shocks in the second half of the 90s such as East Asian economic crisis in 1997-1998 and Luxor massacre 1997.

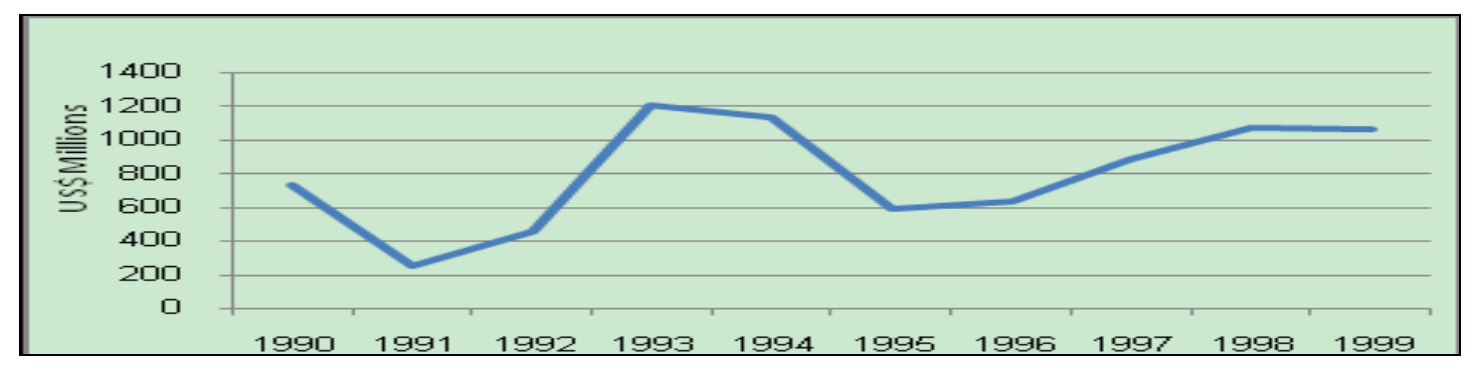

Figure 2. Egypt FDI inflows in 90s

As shown in Figure 3, FDI flows to Egypt varied throughout the period from 2000 until 2010, when new cabinet appointed in 2003, FDI inflows to Egypt was decreasing to reach US\$237.3 million, which is the least amount of FDI since 70s. If one took a depth look, one can notice that rise of FDI to Egypt started in 2004, and continued successively until reaching its peak in 2007 , not only for enhancing investment climate but also as a result of large 
privatisations waves and acquisitions and mergers of State Owned Enterprises (SOEs). After a while, the situation changed dramatically in 2008, FDI inflows to Egypt decreased repeatedly to reach US\$ 6.37 billion.

The Egyptian economy has been confronted with several external shocks during this period. From 1998, the growth rate started to decline due to the combined effect of three external shocks: the emerging market crises, the Luxor incident and the sharp decline in oil prices. These external factors put negative pressure on the current account in the balance of payments, further aggravated by external capital outflows. This was followed by the impact of the global economic consequences of the September 11 attacks in 2001. The situation was further worsened by the war on Iraq, the consequent uncertain political conditions in the region, and the sluggish overall global environment.

This slowdown was evident in real sector indicators and in privately conducted business surveys although 2009 had biggest decline in FDI to reach US\$ 5.96 billion resulted from the negative effects of global financial crisis, in 2011, due to political uncertainty, unprecedented security challenges and widespread labor protests that accompanied the January 25 Revolution have interrupted the trend of FDI inflows to Egypt, which made a negative inflow to reach US\$ -482.7 million, but in 2012 the inflow soared to 2.8 billion due to the Qatar political support.

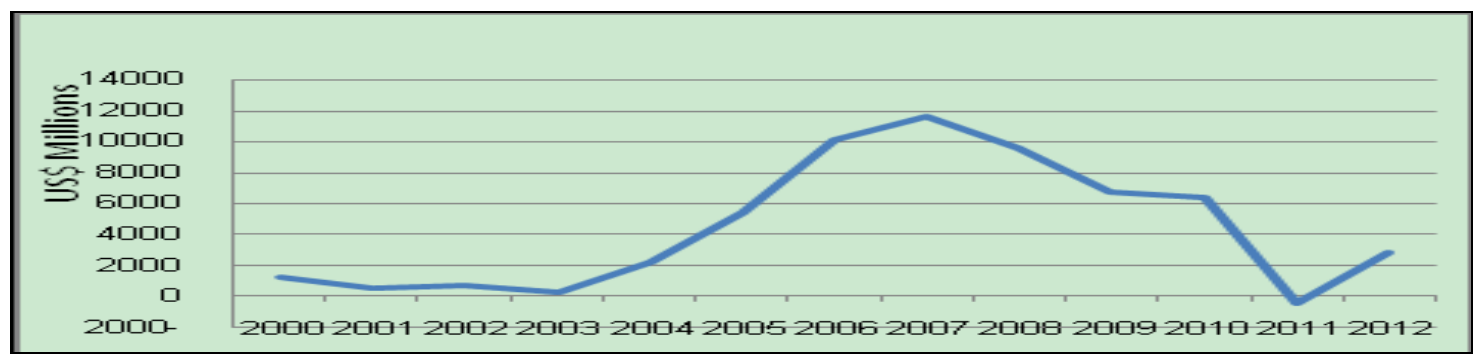

Figure 3. Egypt FDI inflow from 2000 to 2012

By studying the structure of FDI inflow to Egypt, one can found that since 2007 to 2012 (as shown in Figure 4), FDI flows into Egypt have been distributed and diversified in different industries such as natural gas extraction and Petroleum and related activities accounted for $58.32 \%$ of total FDI inflows. Financial services have managed to attract sizeable amounts of FDI Inflow, approximately $8.07 \%$ of the total over the same period, mainly as a result of large privatisations and mergers and acquisitions. IT and communications, which soared from $5.77 \%$ in 2009 to $11.92 \%$ in 2012 with average of $5.63 \%$ of total FDI inflow during the period. Agriculture fluctuated from $0.24 \%$ in 2007 and $2.38 \%$ in 2010 to $0.70 \%$ in 2012 with average of $0.79 \%$ of total FDI inflow during the period. Manufacturing which decreased from $8.64 \%$ in 2009 to $6.13 \%$ in 2012 with average of $7.12 \%$ of total FDI inflow during the period. Construction fluctuated from $0.46 \%$ in 2007 and $2.38 \%$ in 2008 to $1.08 \%$ in 2012 with average of $1.64 \%$ of total FDI inflow during the period. Real estate fluctuated from $0.30 \%$ in 2007 and $2.77 \%$ in 2010 to $0.73 \%$ in 2012 with average of $1.44 \%$ of total FDI inflow during the period. Tourism, dropped from $3.28 \%$ in 2007 to $0.35 \%$ in 2012 with average of $1.57 \%$ of total FDI inflow during the period. Other services which soared from $2 \%$ in 2007 to $3.95 \%$ in 2012 with average of $3.32 \%$ of total FDI inflow during the period. Undistributed, fluctuated from $15.8 \%$ in 2007 and $21.85 \%$ in 2008 to $4.87 \%$ in 2010 then increased to $13 \%$ in 2012 with average of $12.38 \%$ of total FDI inflow during the period.

However, following the global trend, high value-added activities for instance financial services, manufacturing, real estate and construction were hit hard by the international financial crisis in 2008. Accordingly, not only has there been a decrease in the absolute amount of FDI inflows attracted by these industries but also in their relative shares. One must differentiate between two types of FDI in terms of easy escape in case of economic and political unrest. The first type is the investment that works in service areas and other investments which can be liquidated or temporarily frozen. The second type is the heavy investment, which cannot be frozen or filtered easily, for instance investments in the agricultural, industrial production sectors, real estate or hotel sector, these investments does not have a choice except to stay in the market until conditions improve. It is noted that investment concentrated toward service activities with increased instability forecasting, which is what happened in Egypt since 2007. 


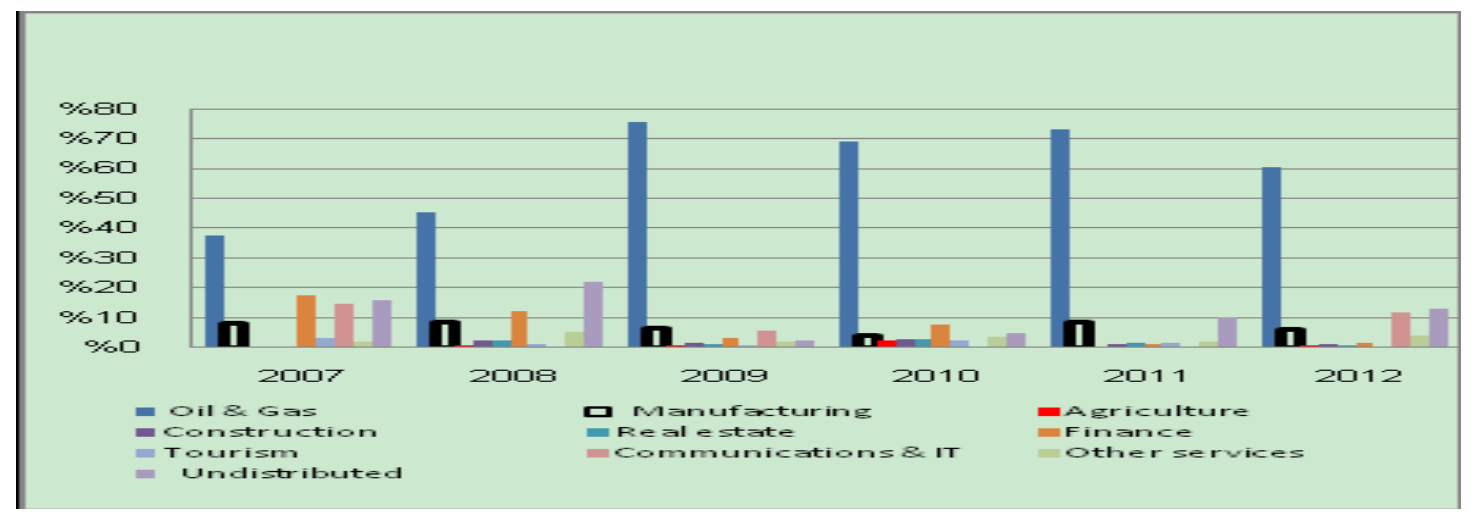

Figure 4. Distribution of inward FDI by industry

\subsection{The Impact of FDI on Activating the Egyptian Securities Market}

Securities market has a positive aspect represented in its important role in achieving economic development through availing an additional channel in addition to banks and self-finance, to finance establishment of new companies or expanding existing companies through offering deferent securities also, it maintains economic stability from availing opportunity to assets property transfer apart from assets despite this good aspect of securities markets, especially in developing countries, they have a negative aspect and the most dangerous is when these markets become a gambling field only as capitals flows to Egypt, for investment in portfolio represented in foreigners deals in Egyptian exchange, is a one of main components of capital account Egypt began in freeing under program of economic and financial reform and structure adaptation as it took many procedures to free capital deals balance account in payment balance, as it was necessary to study foreign investor role in Egyptian securities exchange during economic reform period in general as role they play has a great negative or positive effects on Egyptian exchange coherence.

\subsubsection{Analysing Net Foreign Investors Deals in Egyptian Exchange}

Economic reform programs followed by Egypt tried to attract indirect foreign capital in Egyptian exchange, table no. (3) shows net deals of foreign investors in Egyptian exchange from 1996 to 2001 as there is a permanent fluctuation affected by political and economic policies in Egypt and abroad there are increases in years in which Egyptian exchange witnesses some developments through laws and procedures organizing exchange business or through adopting new financial tools net foreigners deals increased considerably from 2005 till 2007 compared to previous years, also it regressed as a result of international financial crises as it reached negative values in 1998 as a result of south east Asia crisis, in 2008 due to international financial crisis and in 2011 after January revolution, the net foreign deal reached negative (990), (2074) and (4160) million pounds respectively.

If one look attentively to analysis of foreign investors deals annually, as purchasers within the period from 1996-2011 we will find that they are affected by many local, territorial and international circumstances, after dealing took place at 1.1 billion pounds purchase in 1996, it increased to reach 51 billion pounds in 1997, then increase in the nest year to reach 3.4 billion pounds at $33.3 \%$ from the former year. This regression was due to stocks façade by Egyptian economy which had negative effects in it performance of such shocks, petrol prices decrease and international economic environment disturbance as a result Asian financial crises in addition to Luxor's accident which had a negative effect on foreign investors in terms of purchase and sale. In 1999, foreigners' purchases increased to 8.8 billion pounds at about $159 \%$ compared to the previous year, therefore net deal movement increased to reach 3.2 billion pounds due to following policy of foreigners' possession of some industries in many fields such as cement industry, especially when developed countries directed to policies of protecting environment against pollution.

In 2000, and as a result of economic stability in Egypt and success in their programs of economic reform, foreign investors gained more trust in Egyptian exchange, accordingly dealing by purchase reaches 11.6 billion pounds at $32 \%$ increase compared to previous year, also net deal increased to reach 4.1 billion pounds achieving $28.1 \%$ increase, however with events of September 2001 witnessed by the U.S, foreigners purchasing deals were effected as they decreased to 4.1 billion pounds at $65 \%$ compared to 2000 , also net deal decreased to be 276 million pounds. 
With the beginning of getting rid of crisis, deals developed in 2002 but cautiously to reach 5.1 billion pounds at $24 \%$ increase compared to previous year, also net deals increased to reach 560 million pounds, purchasing deal remained at the same level in 2003, 5.1 billion pounds, with decision of freeing exchange rate at the same year, net deal increased to reach 798 million pounds of it was 560 million in 2002 .

Although, purchases increased in 2004 and reached 10.026 billion pounds, they were accompanied with sales reached to 9.739 billion pounds after 4.339 billion pounds in 2003 which reduced net deal to be 287 million pounds.

As a result of some positive factors including having a program for Egyptian exchange activation from the beginning of 2005 by ministry of investment including developing financial tools and creating the new tools, in addition to intensifying communication and information technology use and enhancing control and declaration systems, not to mention privatization role of activating exchange deal un-traditionally; 2005 witnessed great motivation in foreigners purchases which reached 47.8 billion pounds at $378 \%$ increase compared to previous year, net that reached 7.03 billion pounds, representing 15\% only of total purchases, this year was the best one for Egyptian exchange compared to previous years in which Egyptian exchange headed all emerging exchanges.

Although this position indicates foreigners trust in Egyptian exchange deals as reflected on purchases increases, net deal and free size left in exchange were low. This proved that these investments are like hot founds flowing quickly to exchange then with drown outside at the same speed making high capitals for securities holders so that receiving economy cant profit from which needs dealing with such funds cautiously as they have negative effect on local dealers in exchange increase of 2005 created new increase in foreign purchases in Egyptian securities market considerably in 2006, as their purchases in this year reached 91 billion pounds and net deal reached 18.5 billion pounds.

Table 3. Net foreign deals movement in Egyptian exchanges from (1996 - 2011)

\begin{tabular}{|c|c|c|c|c|c|c|c|c|}
\hline Year & 1996 & 1997 & 1998 & 1999 & 2000 & 2001 & 2002 & 2003 \\
\hline $\begin{array}{l}\text { Deal movement as } \\
\text { purchases }\end{array}$ & 1096 & 5074 & 3406 & 8836 & 11627 & 4075 & 5130 & 5137 \\
\hline $\begin{array}{l}\text { Deal movement as } \\
\text { sellers }\end{array}$ & 282.7 & 2627 & 4396 & 5611 & 7565 & 3799 & 4570 & 4339 \\
\hline $\begin{array}{l}\text { Net deal movement } \\
\text { (in billion pounds) }\end{array}$ & 0.8133 & 2.447 & $(0.99)$ & 3.225 & 4.062 & 0.276 & 0.56 & 0.798 \\
\hline Year & 2004 & 2005 & 2006 & 2007 & 2008 & 2009 & 2010 & 2011 \\
\hline $\begin{array}{l}\text { Deal movement as } \\
\text { purchases }\end{array}$ & 10026 & 47811 & 91138 & 90014 & 101126 & 55582 & 840 & 194 \\
\hline $\begin{array}{l}\text { Deal movement as } \\
\text { sellers }\end{array}$ & 9739 & 40780 & 72632 & 81954 & 103200 & 54582 & 997 & 4354 \\
\hline $\begin{array}{l}\text { Net deal movement } \\
\text { (in billion pounds) }\end{array}$ & 0.287 & 7.031 & 18.506 & 8.06 & (2.074) & 0.996 & 7.403 & $(4.16)$ \\
\hline
\end{tabular}

Source: data from 1996 to 2005 taken from "annual report about Egyptian exchange performance" ministry of foreign trade, information centre (different issues). Data from 2006 to 2009 taken from Egyptian exchange, annual book of mentioned years. Data between 2010 and 2011 taken from: public authority of financial control, annual book. 
Table 4. Relative weight of foreigners deals in Egyptian exchange from (1996-2011)

\begin{tabular}{ccccccccc}
\hline Year & $\mathbf{1 9 9 6}$ & $\mathbf{1 9 9 7}$ & $\mathbf{1 9 9 8}$ & $\mathbf{1 9 9 9}$ & $\mathbf{2 0 0 0}$ & $\mathbf{2 0 0 1}$ & $\mathbf{2 0 0 2}$ & $\mathbf{2 0 0 3}$ \\
\hline $\begin{array}{c}\text { Ratio between foreigners } \\
\text { purchase and total trading } \\
\text { amount in percentage }\end{array}$ & 33.4 & 25 & 18.4 & 26.9 & 27.98 & 16.5 & 19.9 & 22.3 \\
$\begin{array}{c}\text { Ratio between foreigners } \\
\text { purchase and total trading } \\
\text { amount in percentage }\end{array}$ & 8.6 & 13 & 23.8 & 17.1 & 18.1 & 15.4 & 17.7 & 18.9 \\
\hline Year & $\mathbf{2 0 0 4}$ & $\mathbf{2 0 0 5}$ & $\mathbf{2 0 0 6}$ & $\mathbf{2 0 0 7}$ & $\mathbf{2 0 0 8}$ & $\mathbf{2 0 0 9}$ & $\mathbf{2 0 1 0}$ & $\mathbf{2 0 1 1}$ \\
\hline $\begin{array}{c}\text { Ratio between foreigners } \\
\text { purchase and total trading } \\
\text { amount in percentage }\end{array}$ & 27.7 & 31.8 & 33.6 & 32.5 & 28.9 & 16.7 & 2.6 & 0.13 \\
$\begin{array}{c}\text { Ratio between foreigners } \\
\text { purchase and total trading } \\
\text { amount in percentage }\end{array}$ & 27 & 27 & 26.8 & 29.6 & 29.5 & 16.4 & 0.31 & 2.9 \\
\hline
\end{tabular}

Source: the same sources, in series.

By circumstances changed in 2007 as there was a regress in purchased associated with sales resulted in reducing foreigners deals in exchange to reach 8.06 billion bounds after 18.6 billion pounds in previous year. Also compared to 2008 , sales increase contained as they were $26 \%$ compared to 2007 in a manner exceeded purchases and this resulted in a negative net deal reached 2.1 billion pounds due to Egyptian exchange affection by international crisis happened in U.S.

Accordingly, 2009 was challenging for developed and developing world economies like in dealing with implications of international financial crisis in this year Egyptian exchange recovered as net deal was directed to positivity and reached one billion pounds and foreigners purchases exceeded foreigners' sales at 1.8\% which proved Egyptian exchange power interns of crisis. 2009 witnessed registering more than new 36 thousands investors in Egyptian market to make "coded" investors more than 1.7 million which reaffirmed permanent trust in Egyptian exchange. Non-Arab foreign organizations recorded the highest growth. In number of registered in 2009 at $12 \%$ while Arab organisation reached 5.4. This resulted in increase in non-Egyptian organisations working in Egyptian market more than 11500. Individual investors reached the highest percentage in market deals that reached $63 \%$ of total foreigners deals in market compared to $66 \%$ in previous year which made foreigners purchases in Egyptian exchange exceed their sales amount by 996 million ponds.

Consequently, Egyptian exchange in 2010 took procedures aiming at more organisation and supporting markets efficiency and integrity to regain investor trust in Egyptian exchange. This year witnessed reviewing a great number of lows and legislations organising capital market, in addition to brokerage companies branches regulations and rates of issuing international depositing certificates and norms of registering companies working in Egyptian exchange also the same year witnessed amends in roles of registration and declaration as Egyptian exchange contributed in establishing the first association of developing investors relationships aiming at changing methods followed in companies management of their relationship with local potential investors to support declaration.

Hence, Egyptian exchange attracted more foreign investors for 2010 as annual report of Egyptian exchange confirmed that it received great foreign flows, as in this year net foreigners deals reached 7.4 billion pounds. The report recorded that net foreign investment purchased, as in table 8.4, against net sale of 997 million pounds. Organisations possessed $51.7 \%$ of total deals for this year and the remaining deals, $48.3 \%$, were possessed by individuals. Egyptian deals recorded $77.4 \%$ of total deals in market compared to $16.4 \%$ non-Arabs foreigners and 6.16\% Arabs. At countries level, British investor possessed 37\% of total foreigners deals within 2010 followed by U.S. investor at $24 \%$ but Arab investors were headed by U.A.E investor at $10 \%$ while Saudi Arabia possessed $6.9 \%$ of total foreigners deals the annual exchange report in 2010 indicated that individual investors recorded increase of 30855 new investors against 36676 investors in previous year while individual non-Arab foreigners investors recorded more than 1300 foreign investors in 2010 compared to 342 foreign investors registered in 2009.

In 2011, foreign investors' deals suffered from unstable events in Egypt since 25 January revolution as sales size of 4.35 billion pounds exceeded purchases size of 194 billion pounds which rendered negative net dealing where by 
viewing this position and comparing to previous year. We will find that sales size is not more than half foreign investment entered Egyptian exchange in 2010 which reached 8.4 billion pounds. At the level of Egyptians and foreigners deals, we find that in 2011, foreigners possessed $20 \%$ of total market deals and at countries level, British and U.S possessed $41 \%$ and $27 \%$ respectively of total foreigners' deals within 2011 followed by Saudi Arabia and United Arab Emirates at 8\% and 5\% respectively.

For number of foreign investors, about 1500 foreign investors were registered in Egyptian exchange in 2011 most of them are foreign organisations, while Arab investors reached 883 investors. Egyptian or foreign organisations possessed within this year the highest percentages of such deals in market as their deals percentage reached $59 \%$ of total market deals compared to $52 \%$ in previous year while individuals percentage within the year reached $41 \%$ compared to $48 \%$ for previous year. If one considered net foreigners portfolio in Egyptian payment balance, one will find that profits of 731 million dollars were transferred abroad within 2 years 2002/2003 at 405 million dollars and 2003/2004 at 326 million dollars.

As showed in figure at Figure 5, it is clear that when comparing net foreign investors deals in Egyptian exchange since 1996 and till 2010 with some market indicators like market capital and value of issues in primary markets, net foreigners deals have striking role in activating Egyptian exchange and also represent quick cash flows which may exit quickly as entered quickly.

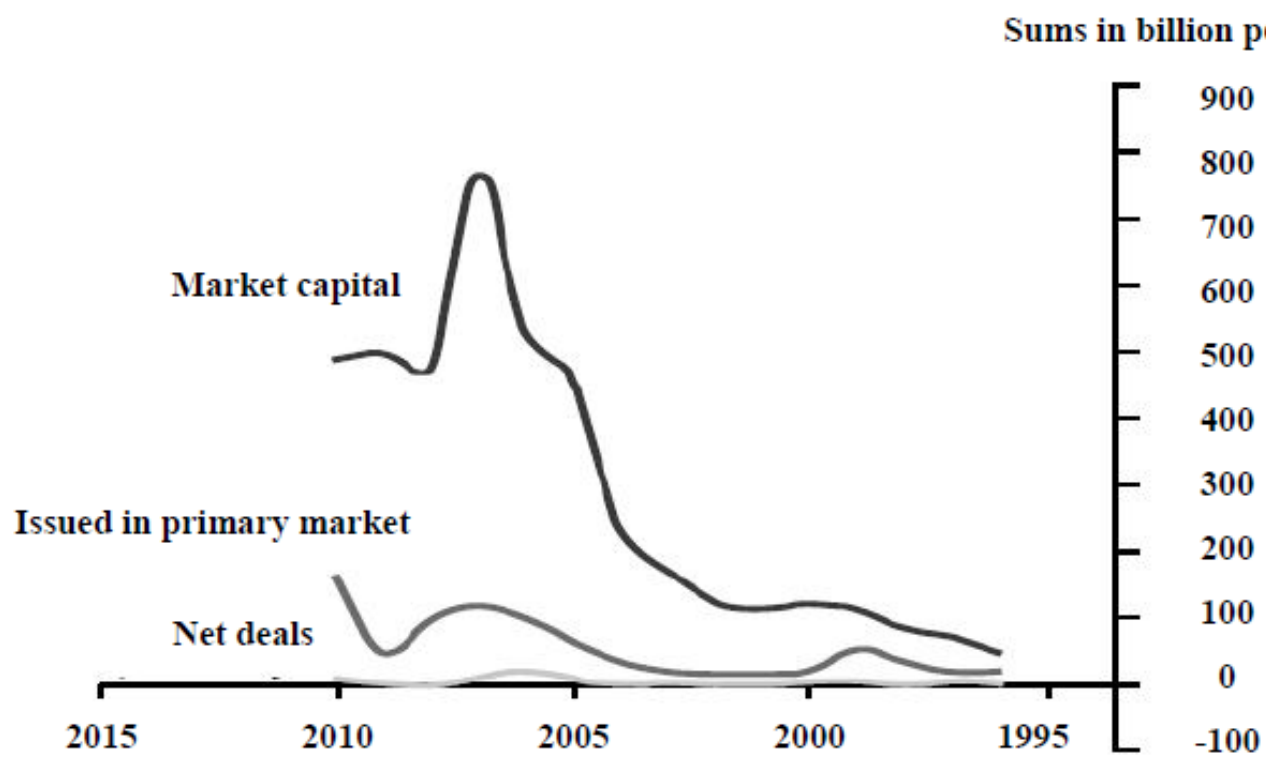

Figure 5. Foreign investors deals in Egypt in exchange 1996 - 2010

\subsubsection{Relative Weight of Annual Foreign Deals from 1996-2010}

For developing relative importance of foreign investors deals in Egyptian exchange annually from 1996 to 2011 as shown in table (4) they are found fluctuating due to reflection of political, economic and financial effects. They increased from $16.5 \%$ in 2001 to $19.9 \%$ in 2002 to $22.3 \%$ in 2003 to $27.7 \%$ in 2004 to $31.7 \%$ in 2005 then finally increased to 33.6\% in 2006. Dealers from Golf states (Saudi Arabia, Emirate, Kuwait) represented about 36\% of total foreign dealers in 2004 and about $41 \%$ of total foreign dealers in 2005 , as a reflection of liquidity resulting from international petrol prices increase then reduced to $28.9 \%$ in 2008 due to international financial crisis.

Great growth in portfolio investments flows and the increase in relative share of foreign dealers of total can be explained by privatization expansion and selling to a main investors from one side and high rates of return achieved for foreign investors in Egypt compared to other emerging and developed markets from the other site.

The same applies to comparing percentage of foreigners'. 


\section{Conclusions and Recommendations}

\subsection{Conclusions}

In this study, the researcher attempted to explain the results obtained in the empirical literature on FDI's determinants and effect on growth in host countries, using evidence from developing countries with analysing Egypt as case study. The sample period for the research undertaken is 1961-2012. Since then two major developments have shaken the FDI Inflows in Egypt. First, the Global Financial Crisis that started 2008 has had a major impact on the Egyptian economy. Second, the beginning of Arab Spring revolutions 2011 and its disturbances of political straggle till now.

The researcher found that the determinants that attract FDI in Egypt are GDP, economic openness, general government expenditure and Employment. However, these factors varying from country to another. In general, countries with large trade market potentials and relatively higher contribution of industries to GDP are more likely to be successful in attracting FDI. This could lead us in the future studies to consider new variables that could explain the attraction of the FDI.

On the other hand, the researcher found that FDI has very weak and non- significant effect on GDP growth in Egypt. These findings are important for policy making to design FDI promotional policies. During the second half of the past decade, Egypt became a major recipient of FDI among developing countries. Not just favorable external conditions coinciding with major internal reforms were the main drivers of growing FDI inflow that reached a record high both in absolute terms and relative to GDP during this period, but also large privatisations and mergers and acquisitions of public enterprises in this period. The recent financial and economic crisis which started 2008 brought an end to this upswing and continue deterioration in receiving FDI as a result to foggy and uncertainty of political situation, unprecedented security challenges and widespread labour protests that accompanied the January 25 Revolution then followed by power struggle and lack of Legitimacy.

One must give attention to the quality of foreign investment. The researcher notes that the experience of Egypt with such investments is not all positive. For example, $60 \%$ of FDI in Egypt go to the sectors are not labour-intensive (Petroleum and Energy Sectors). More precisely, it does not create jobs and thus do not contribute much to solve the problem of unemployment, which reached almost $12 \%$ this year, which was the primary reason the revolution of January 25.

Moreover, one should not overlook the fact that the main reason for the ineffectiveness of the FDI in the GDP growth was the absence of an investment map of most promising geographical areas in Egypt in addition to the absence of flexible attractive policies and effective in dealing with investor to attract more investments, as well as the proliferation of bureaucracy, obstacles facing investment, lack of skilled, trained personnel required for the projects. In addition, as noticed that there is ineffectiveness of distribution of FDI inflow to economic sectors, FDI inflow dominated by petroleum, gas and tourism sectors while the industrial and agricultural sectors are negligible.

Finally, regarding the role of FDI in activating the stock exchange, if Arab and foreign capitals fail to be directed in exchange to under writing in capital increase and financing expansion in project, activity and increasing investment rate, the effect expected for these flows will be directed to appreciating local currency (including negative effects in competitive position of non-petrol exports) and not pushing economic growth rate. Accordingly, exchange rate in a weak position in Egyptian economy in which any foreign striking operation can affect stability which imposed considering norms controlling foreign funds movement. Moreover foreigners' entrance and exiting Egyptian exchange without restrictions supports speculating shares prices and without these funds stability mechanisms (especially profits and re-investing in exchange for at least certain period) rate of exchange is subject to fluctuation under economic freedom and neglecting its risks.

\subsection{Recommendations}

1. Based on empirical findings, the researcher suggest to adopt and creating business friendly environment through a reduction in corruption and the expansion of infrastructural facilities. Also, government should facilitate and clarify the laws and procedures governing the business and develop some necessary institutions to reduce the extent of corruption and to control the factors that increase both visible and invisible business start-up costs.

2. Despite the competition to attract FDI, the Egyptian government shouldn't rush towards attracting FDI and going for its quantity against its quality. Thus, the officials should get the investments aimed at a quick profit and benefit from the deformation of the price structure which weaken the body economic rather than strengthen it. 
3. To limit affection by world international crisis, the Egyptian capital market authority (CMA) can refer to some procedures expected to be taken by Egypt or developing or emerging countries through which foreigners deals can be transferred to long term investment instead of speculation: a- direction to structural reforms procedures before freeing capital market. b- Regular series of freeing capital account. c- careful financial control on these flows, through studying foreign investors behaviors inside emerging markets for developing suitable policies towards such behaviors and market stability.

4. Despite the weakness of the impact of FDI on growth, the Egyptian government should put good policies during its quest to attract foreign investment. For instance, the Government could:

i) Care about FDI diversified among various economic sectors. And ensure that the FDI is not focus in a particular sector.

ii) Give preference to FDI which help to reduce imports (imports substitutes) where helps to improve the exchange rate of the local currency.

iii) Give importance to medium or long-term FDI projects, rather than short-term to ensure a serious foreign investor and ensure the stability of the investment climate.

iv) Give prominence to FDI projects which invest in capital goods where help to increase technology transfer.

v) Give preference for FDI which have high wages component to maximise the employment opportunities where contribute to the equitable income distribution.

5. To reduce risks to which developing countries' economies are exposed as a result of sudden entrance and exit of foreign capitals, these norms ranged between determining percentage possessed by foreign investor in a company to impose high taxes limiting re-transferring funds to the original country, some countries relatively facilitate entrance of funds while it is difficult to return investment profits to the investor's country. Accordingly capital exit may be subject to governmental approval.

\section{References}

Agarwal. (1980, December). Determinants of foreign direct investment: A survey. Review of World Economics, $116(4), 739-773$.

Aharoni, Y. (1999). The Foreign Direct Investment Process, Boston, Harvard Business School, 1966. The Internationalization of the Firm, Cengage Learning EMEA, pp. 3-14.

Amal, M., Raboch, H., \& Tomio, B. (2009). Strategies and Determinants of Foreign Direct Investment (FDI) from Developing Countries: Case Study of Latin America. Latin American Business Review, 10, 73-94. http://dx.doi.org/10.1080/10978520903212532

Badr, Osama M., \& Ayed, Tahar L. (2015). The Mediator Role of FDI in North Africa: Case of Egypt. Journal of Advanced Management Science, 3(1), 1-7. http://dx.doi.org/10.12720/joams.3.1.1-7

Banga, R. (2009). Impact of government policies and investment agreements on FDI inflows. ICRIER, New Delhi, Working Paper NO. 116.

Bashir, A. M. (1999). Foreign direct investment and economic growth in some MENA countries: Theory and evidence. Department of Economics, Grambling State University.

BCG. (2009). The 2008 BCG 100 New Global Challengers: How Top Companies from Rapidly Developing Economies Are Changing the World. Boston: Boston Consultancy Group.

Bende-Nabende, J. Ford, B. Santoso, \& S. Sen. (2003). The interaction between FDI, output and the spillover variables: Cointegration and VAR analyses for APEC. Applied Economics Letters, 10(3), 165-172. http://dx.doi.org/10.1080/1350485022000044057

Bhattacharya, P. Montiel, \& S. Sharma. (1996). Private capital flows to sub Saharan Africa: An overview of trends and determinants. World Bank, Washington DC, Mimeo.

Bowen, G. A. (2003). 'Social funds as a strategy for poverty reduction in Jamaica': An exploratory study (Doctoral dissertation, Florida International University. Dissertation Abstracts International, 65, 1557.

Carkovic, M. V., \& R. Levine. (2002). Does foreign direct investment accelerate economic growth? U of Minnesota Department of Finance Working paper.

Chakrabarti, A. (2003). The determinants of foreign direct investments: Sensitivity analyses of cross-country regressions. Kyklos, 54(1), 89-114. http://dx.doi.org/10.1111/1467-6435.00142 
Clarke, P. N., \& Yaros, P. S. (1988). Research blenders: Commentary and response. Nursing Science Quarterly, 1, 147-149. http://dx.doi.org/10.1177/089431848800100406

ECLAC (ECONOMIC COMISSION OF LATIN AMERICA AND CARIBBEAN). (2009) La Inversín Extranjera Directa en América Latine y el Caribe. Santiago: United Nations.

Enderwick, P. (2009). Large emerging markets (LEMs) and international strategy. International Marketing Review, 26(1), 7-16. http://dx.doi.org/10.1108/02651330910933177

Gao, T. (2004). FDI openness and income, The Journal of International Trade \& Economic, 13(3), 305-323. http://dx.doi.org/10.1080/0963819042000240048

Hymer. (1976). The International Operations of National Firms: A Study of Foreign Direct Investment. Cambridge: MIT Press.

James, R. (1975). The nature and determinants of export-oriented direct foreign investment in developing country: A case study of Taiwan. Review of World Economics, 111(3), 505-528.

Jansen W. J., \& A. Stokman. (2003). Foreign direct investment and international business cycle comovement. Retrieved from http://www.dnb.nl/binaries/ms2003-10_tcm46-147340.pdf

Lensink, R., \& Morrissey, O. (2001). Foreign direct investment: Flows, volatility and growth in developing countries. Retrieved from http://irs.ub.rug.nl/ppn/239757564

Lim, E. G. (2001). Determinants of and the relation between foreign direct investment and growth: A summary of recent literature. IMF Working Paper.

Lipsey. (2002). Home and host country effects of FDI. NBER Working Paper. No. 9293. Retrieved from http://www.nber.org/chapters/c9543.pdf

Madhok, A. (2010). Acquisition as entrepreneurship: Internationalization, acquisition and multinationals from emerging economies. Schulich School of Business, York.

Masry, Mohamed. (2015c). The role of economic stability in achieving economic development. Journal of Economics and Sustainable Development, 6(16), 134-153. Retrieved from www.iiste.org

Masry, Mohamed. (2015f). The Impact of Stock Split on Stock Prices in the Egyptian Stock Market. Research Journal of Finance and Accounting, 6(20), 116-135. Retrieved from www.iiste.org

Massey, J. E. (2003). Managing organizational images: Crisis response and legitimacy restoration. Managerial and Decision Economics, 22(2), 245-257.

Mudambi, R., \& Navarra, P. (2002). Institutions and internation business: A theoretical overview. International Business Review, 11(1), 35-55. http://dx.doi.org/10.1016/S0969-5931(01)00046-4

Nachum, L. (2003). Liability of foreignness in global competition? Financial service affiliates in the City of London. Strategic Management Journal, 24(12), 1187-1208. http://dx.doi.org/10.1002/smj.347

Pangarkar, N., \& Lim, H. (2003). Performance of Foreign Direct Investment from Singapore. International Business Review, 12, 601-624. http://dx.doi.org/10.1016/S0969-5931(03)00078-7

Peng, M., Wang, D., \& Jiang, Y. (2008). An institution-based view of international business strategy: a focus on emerging economies. Journal of International Business Studies, 39, 920-936. http://dx.doi.org/10.1057/palgrave.jibs.8400377

Root F., \& Ahmed, A. (1979). Empirical determinants of manufacturing direct foreign investment in developing countries. Economic Development and Cultural Change, 27, 751-767. http://dx.doi.org/10.1086/451139

Santiso, J. (2007). The Emergence of Latin Multinationals. Deutsche Bank Research. Retrieved from http://www.dbresearch.com/PROD/DBR_INTERNET_ENPROD/PROD0000000000207831.pdf

Sechrest, L., \& Sidana, S. (1995). Quantitative and qualitative methods: Is there an alternative? Evaluation and Program Planning, 18, 77-87. http://dx.doi.org/10.1016/0149-7189(94)00051-X

UNCTAD. (2013). Website from the United Nations Conference for Trade and Development.

University, Working paper, June 1, 2010.

Wheeler, \& A. Mody. (1992). International investment location decisions, the case of US firms. Journal of International Economics, Amsterdam, Elsevier, 33, 57-76. World Bank Data (WDI). http://dx.doi.org/10.1016/0022-1996(92)90050-T 